This item was submitted to Loughborough's Research Repository by the author.

Items in Figshare are protected by copyright, with all rights reserved, unless otherwise indicated.

\title{
Contemporary feminist discourses and practices within and across boundaries: an interview with Avtar Brah
}

PLEASE CITE THE PUBLISHED VERSION

https://doi.org/10.1057/s41305-017-0079-2

\section{PUBLISHER}

Palgrave Macmillan @ The Feminist Review Collective

\section{VERSION}

AM (Accepted Manuscript)

\section{PUBLISHER STATEMENT}

This work is made available according to the conditions of the Creative Commons Attribution-NonCommercialNoDerivatives 4.0 International (CC BY-NC-ND 4.0) licence. Full details of this licence are available at: https://creativecommons.org/licenses/by-nc-nd/4.0/

\section{LICENCE}

CC BY-NC-ND 4.0

\section{REPOSITORY RECORD}

Brah, Avtar, and Clelia Clini. 2019. "Contemporary Feminist Discourses and Practices Within and Across Boundaries: An Interview with Avtar Brah”. figshare. https://hdl.handle.net/2134/32162. 


\section{Contemporary feminist discourses and practices within and across boundaries: an interview with Avtar Brah for Genre, Sexualite et Societé}

Dear Professor Brah, first of all, thank you for agreeing to this interview. As you know, this issue of the journal is specifically focused on feminism and on the production, circulation and consumption of images (in the arts as well as in the media) related to gender and sexuality. As we are adopting an interdisciplinary approach to the analysis of feminism, our aim is also to expand the debate by bringing in feminist voices from different fields and locations, so to explore the "boundaries" and the crossing of boundaries of feminist discourses and practices. We are thus interested in the "wordliness", to borrow Edward Said's words, of feminist discourses and practices as well as in the dynamics of power that shape feminist discourses as well as contemporary discourses on feminism. As a feminist scholar and an activist you could certainly help us in developing a debate on these issues.

1) For a start, we would like to ask about your own approach to feminism and feminist politics. Could you please comment on how your own experiences of having been born in Panjab and raised in Uganda, and your subsequent experience of studying in the US and the UK, have influenced your approach to feminism?

I was born in Panjab and went to Uganda at the age of about six. During my early school years Uganda was still a colony or a 'protectorate' to be precise. Uganda achieved independence during my high school years so that I learned what it meant to live in a society in which White Europeans were at the top, Black Africans were at the bottom, and the South Asians were in the middle. You became tuned into viewing the world within and across this racial and class divide. At a personal level, I became aware of the social and psychological impact of the simultaneous positionality of dominance and subordination, and of the complex entanglements of colonial power hierarchies. Gender was inextricably linked with the workings of this coloniality as well as caste and religious differences. I remember that when Uganda became independent, I was sent to stay with an uncle and aunt's family in Tanzania because my parents had memories of the carnage at the time of Indian Independence from Britain in 1947, when Panjab was partitioned and during the mass movement of population across the borders of newly created Pakistan women were subjected to sexual violence and rape from all sides. This fear of sexual violence was transposed to the Ugandan case where in reality no such incidents, to my knowledge, took place. Anxieties about black male sexuality together with those of men of different castes and religions were due to the South Asian practice of caste and religious exogamy. These prohibitions did not affect general everyday social interactions among South Asians but came to the fore whenever these boundaries were challenged by potential sexual liason across 'race', caste or religion.

My consciousness as a child about anti-colonial politics were influenced by radio news bulletins about the Mau Mau struggles in Kenya, the tales of Indian Independence struggles, and some Indian films which provided progressive visions of society. On gender issues, the Panjabi poet and novelist 
Amrita Pritam and the novelist Nanak Singh, and the poet Sahir Ludhianvi were my guide. I was introduced to their works when I was about twelve years old, and I was nurtured by their nuanced but trenchant critiques of patriarchal values.

I had a strong identification with Uganda as home. I stayed up late into the night to listen to the commentary on radio in Tanzania, as the Ugandan flag was raised at the independence ceremony in 1962. I felt a sense of deep pride when the national anthem was played. Of course, I know now how such patriotic sentiments can also be mobilised in the name of nationalisms such as those that stalk Europe today. My identity of 'Ugandan of Asian origin' provided me with a means of reflection on the nature of hybrid identities, and the power dynamics which underpin them.

When I went to the USA in the late 1960s, I became involved in student politics and became aware of the plight of black Americans . The Civil Rights Movement and The Black Power Movement prevailed as a potent political force. The grapes boycott with Caesar Chavez as its leader drew attention to the conditions of migrant labour in California. The interconnections between gender, race and class were now beginning to impinge on my consciousness though the language of race and class or patriarchal relations was not yet part of my everyday vocabulary. I was also attracted to the message of the peace movement, and was active in the anti-Vietnam war politics. At the same time, the flower power of the 'Hippy' groups was also attractive. All this made me question the relative merits or otherwise of militant vs pacifist political strategies and action. I came to Britain from the USA during the early 1970s, and became a refugee when Idi Amin expelled Asians from Uganda and I could not return. Here, I came to be engaged in socialist feminist politics, initially through the Women's Liberation Movement but later through the aegis of Black Women's groups such as the Organisation of Women of Asian and African Descent, and Southall Black Sisters. These feminist politics analysed patriarchal relations within their global context of colonialism and imperialism. We examined gendered class inequities and inequalities of the global South and North, interrogated their relationality, and attempted to develop strategies for change that were sensitive to these broader transnational interconnections.

2) You are often cited as a key figure of transnational feminism. Could you please tell us how you define transnational feminism and what do you think is its use nowadays?

Transnational feminism is about understanding how patriarchal relations are enmeshed within power geometries of global relations. Global inequities and inequalities underpin, construct and position different patriarchal formations in relation to one another. That is to say that, in order to address gender relations today we need to examine how and in what ways they are impacted upon by imperial/neo-imperial and colonial/postcolonial power dynamics. Contemporary global socio-political, economic and cultural configurations have a critical bearing on inscribing gender relations. For instance, to speak of Pakistani Muslim women in Britain means we must address the history of colonial relations between Pakistan and Britain, and the resonance of these in the postcoloniality of Britain in its global context today. The life experiences 
of these women are impacted upon not only by patriarchal relations prevailing within Pakistani groups (with all their class, regional, and linguistic internal differences) but also by gender relations as they exist in British society as a whole. These patriarchal relations are refracted through the prism of racism. Britain's role in the wars in the Middle East and its fall out, especially in the emergence of Islamophobia, is highly relevant to understanding the lives of Pakistani women. The discourse of 'muslim woman' is singularly orientalised and racialised. There have been instances of Muslim women being subjected to racial abuse, attacked on the street, and some of their items of clothing, especially the hijab, being pulled off their heads. The power of 'whiteness' has its bearing on how Muslim women are discursively constructed and represented.

As feminists, we take it as a given that we critique and challenge patriarchal formations. Yet we need also to be attentive to how different categories of people are 'Othered'. White women are 'othered' but differently from Women of Colour and there are power relations inscribed in this relationship which need to be taken into account. Similarly, trans people are differently sexualised than bi-sexuals, queers, and heterosexuals. There are global dimensions to all these. Transnational feminism keeps us attentive to these differentials and divisions.

3) You have been one of the strongest advocates of intersectionality. In "Cartographies of Diaspora" you discussed the condition of South Asian Muslim women working in the UK and the gendered and racialised discourses built around them. What do you think has changed in the past 20 years? How do you think dominant discourses tend to frame immigrant Muslim women in the UK, and Europe in general, nowadays?

Much has changed in the last twenty years - somethings for the better and others for the worse. The 9/11 destruction of the Twin Towers in New York in 2001 ushered a new phase in global relations. Trust between different groups was replaced by suspicion. The 'War on Terror' unleashed polarising forces. The wars in Afghanistan, Iraq, Libya, Syria, South Sudan and so on have devastated whole regions of the globe. Economically, neo-liberal regimes have taken root globally and deepened global inequality. The proliferation of new information technologies and social media have nurtured new and instantaneous modes of communication bringing the world closer, but at the same time they simultaneously entrench technologies of surveillance and control. After the 1989 fall of the Berlin Wall there was hope for global peace, but this hope has been depleted and we seem to have a new 'cold war' between Russia and the West which seriously threatens world peace. Floods, tsunami, droughts and other environmental degradation exacerbate the conditions of world poverty which set new population movements in train. It is in this broader context that gender relations are currently played out. Muslim women have been orientalised in western discourses for a very long time, but they are now subjected to a new racism called Islamophobia, and are represented as a threat par excellence to the very core of 'western civilisation'. They are socially constructed as the polar opposite of the 'western woman'. Of course, whilst many Muslim women remain one of the most disadvantaged 
groups in Britain, others have done well in all areas of life. There are journalists, Members of Parliament, entrepreneurs, academics, professionals, and so on. Intersectionality teaches us to analyse the intersections of such differential locationality, and representation. It focusses on the interlinks between gender, race, class, sexuality, disability and so on under such global geo-political scenarios.

4) How do you think an intersectional framework of analysis could be helpful in understanding the social and political events of our time? I'm thinking especially of the current "refugee crisis", but also of the impact of Brexit on the lives of immigrant women-what do you think of the ways in which refugees are framed in dominant discourses (in the UK and Europe)?

Intersectionality, as Ann Phoenix and I defined it in 2004, signifies the complex outcomes "when multiple axis of differentiation" intersect across economic, political, cultural, psychic, subjective and experiential domains in historically specific contexts. Collins and Bilge argue that “ ... organization of power in a given society are better understood as shaped by not a single axis of division, be it race or gender or class, but by many axis that work together and influence each other (Collins and Bilge 2016:2)". These local and global contexts are intimately intertwined. Above I have described some of the key social and political events of our time. Indeed the "refugee Crisis" is an outcome of the wars, political conflicts, global poverty, and environmental crisis. These factors work together and create conditions which make people flee their homes and become refugees. Of course it goes without saying that the refugee is not a homogenous category. Different subjects and subjectivities emerge depending on the particular axis - such as gender, class, ethnicity, age, and generation -- which articulate and come into play in specific circumstances. The "refugee crisis" is in effect a crisis in global governance in which powerful nations and global political institutions play a central part. The recent and current arrival of refugees in Europe has unleashed virulent racism and xenophobia or xenoracism. In Brexit Britain this has attained levels rarely reached before. Individuals born and brought up in Britain have been told to 'go home' by their fellow citizens. They are blamed for taking their jobs away, for competing with them for housing, education and social welfare. Yet, evidence shows that immigrants and refugees are likely to do jobs locals do not wish to do, and that problems of inequality which affect those at the lower rungs of society are endemic to neoliberal regimes. They are underpinned by government's social, economic, and political policies. There are as we know some critiques of intersectionality one of which is concerned with whether or not intersectionality has its own methodology that differentiates it from that which pertains to subject disciplines. I favour the view that methodologies derived from particular subject disciplines are important and that you frame the analysis using your own specific subject based methodology. I concur with Sumi Cho, Kimberle William Crenshaw and Leslie McCall that " intersectionality is best framed as an analytic sensibility (Cho et.al 2013: 795)" . So, as they argue, you do not regard categories as inherently and completely different and distinct but always permeated by other categories. What is crucial is the nature of the intersection between categories, say gender and race, and its outcomes at the level of 
social structure, subjectivity, identity and experience, marked as they all are by dynamics of power (Brah 1996). It is in this broader sense that intersectionality can help us make sense of problems today.

5) Connected to the previous question is the aftermath of the sexual assaults of New Year's Eve in Germany (2015-2016), which has seen the popular resurrection of issues such as: 1) the need to protect "our" women from the "Other"; 2) the competition of anti-racism and anti-sexism, as feminists have been accused yet again of being silent on the attacks for the sake of antiracism. Could you please comment on that?

Violence against women is endemic in most societies. In Britain, an incident of gender based violence and abuse is reported to the police every minute, largely perpetuated by men against women. Apparently, seven women are killed every month by partners or ex-partners. Sexual harassment at work and in public places is common as a recent Trade Union Congress report demonstrates. This is the context in which the New Year's Eve sexual assault needs to be understood. Without doubt we take a position against such assaults against women while at the same time draw attention to the violence against women perpetrated by men in general. We should not be silent on the attacks but we must simultaneously expose the "rescue narratives" for what they are an attempt to shore up what is mainly white male privilege. Moreover, we must challenge the way in which the actions of a few Muslim men are made to stand for all Muslim men, the seeming assertion being that they are more violent than non-Muslim men which they are not.

6) What do these simultaneous attacks on feminists by several journalists and politicians (in Europe but the US as well) say about feminism in the $21^{\text {st }}$ century?

Feminism in the $21^{\text {st }}$ century is a beleaguered project. The intersectionality of gender, race, and religion is a combustible mix. Understanding these issues demands complex and nuanced analysis which are irreducible to the conventional binaries of Right/Left or secular/religious. But, by the same token, feminism is needed more than ever. We need to be mindful of all that potentially divides us so as to work through strategies to foreground all that we hold in common and that holds us together.

7) What about the state feminism in the US? What are the implications of Trump's election and the Weinstein's scandal?

The election of Trump poses severe challenges for feminist politics. His embodiment of a sexist, aggressive kind of masculinity has become normalised for some sections of the population, which is sympathetic to the neo-con values. As was the case with Thatcherism and Reaganism,, a new common sense has emerged in the wake of Trumpism, in which the values of the new right become common place, so that his supporters include many women. For feminists, the challenge is to dislodge and replace this common sense. This feminist project will have to operate at all levels of the social 
formation - economic, cultural, political, experiential and subjective levels. It will involve the development of whole new sets of diverse practices informed by feminism.

But, of course, women are already engaged in combatting this common sense and resisting sexism in general. The recent scandal of Harvey Weinstein in the film industry is part and parcel of a culture of violence against women. The hashtag \#metoo represents a very significant fight back by women against such violence. It has shown how pervasive and acceptable this violence is across all sectors of society. The reluctance of some men in power to acknowledge the gravity of the situation also speaks of an enduring resistance to change. In a number of cases, there has been victim-blaming and it shows how difficult it is for women to come forward and disclose that they have been violated.

8) In the wake of the 2003 war against Iraq you and Ann Phoenix wrote, in “Aint' I a Woman", that "that feminist dialogues and dialogic imaginations provide powerful tools for challenging the power games currently played out on the world stage”. How would you apply this suggestion to current world politics?

The current world politics is an extremely complex ensemble. On the economic front, inequality persists both within and between nation states. Political strife and wars are converting large and thriving cities in to rubble, making millions homeless. The 2003 war in Iraq was a watershed moment when, among other sites, the Middle East became a major focal point for the $21^{\text {st }}$ Century power manoeuvers for global hegemonies. We live in a strongly polarised world. Human security is under threat, not just from politics of radical extremism the world over but also from state machineries of various global powers through surveillance, control and war. There is a serious question about the links between the foreign policies of some western nations and the various wars waging around us, and the and the role in this of the new 'cold war' between Russia and the West. At the same time there is violence by extremist groups which gives succour to those political actors who regard war as the only solution. Feminist peace movements pose radical challenge to militarised regimes. Yet, there are also divisions amongst feminists about these issues. There were feminists who supported the 2003 Iraq war, and there are others who are currently in favour of the war in Syria. Then there are those of us who prefer political negotiation and peaceful solutions to violence and war. If we had to live in Europe with the everyday devastation of war that people, say, in Syria have to live through, what would our reactions be? We could not afford to be complacent then and would need to find peaceful solutions.

9) Despite the attacks it receives, feminism seems also to be experiencing a newly found popularity nowadays. What do you think are the most pressing issues feminists should focus on these days?

Struggles against global/local economic, political and cultural inequities and inequalities remain paramount. Economic inequalities between men and 
women such as the gender pay gap are still rife. Women are the hardest hit by the austerity policies of governments. Women are underrepresented in the higher echelons of society. Violence against women must be combatted. Trafficking of women is a major issue to be addressed. Racism, xeno-racism and discrimination against migrants, refugees, asylum seekers, people of colour, Jewish people, Muslims, Gypsies, LGBTQ people is one of the most pressing issues to confront us today. The political Right is gaining strength throughout Europe, and is fuelling virulent nationalisms. Strategies to deal with these racisms and nationalisms is an urgent task for feminists. Degradation of the environment is at crisis point and must be addressed with great urgency. Campaigns to end wars through peaceful means, I believe, are a feminist priority. We have a very full agenda.

10) One last question about your involvement with the Feminist Review. As the longest standing member of the collective, how do you think feminism and feminist politics have changed in the past 20 years?

As I noted above, I came to Britain from the USA in the early 1970s when the Women's Liberation Movement was getting off the ground. I became involved in a conscious raising group in Bristol where I was working as a research assistant and doing my $\mathrm{PhD}$ at the same time. We were a predominantly white middle class group. In fact, I was the only woman of colour member. We attended some of the early national feminist conferences. Again there were very few women of colour at the conferences. I remember that at one of conferences, we tried to raise the importance of racism as a feminist issue, but this claim was largely ignored. Questions of sexuality and lesbian politics were also being raised. Gradually I met other feminists of colour in Bristol and we formed a feminist group called Bristol Black Sisters. The term 'black' was then being used as a political colour to bring about solidarity amongst African, Caribbean, and Asian people against colour coded racism in the British context of post-coloniality. Later I moved to London and became one of the founding members of Southall Black Sisters, an organisation which is still active today. Nationally, we were part of the Organisation of Women of Asian and African Descent (OWAAD), a body to which other local organisations were affiliated. Many of us were also socialists, so class politics was also at the centre of our concerns. The journal Feminist Review defined itself as a socialist feminist journal. Hence it was a kind of natural intellectual and political home for me. Some of the key debates of the time around racism, ethnicity, class, sexuality, 'the family', patriarchy, reproduction, domestic labour, subjectivity, psychoanalysis and so on - took place on the pages of feminist Review. Much of the early debates were centred on the binary male/female and the question of the indeterminacy of 'sex' as a category was yet to be addressed.

When, more recently, the question of 'third wave' feminism came to the fore, its advocates recognised the advances made by the 'second wave' but also critiqued some its goals and assumptions. In some 'third wave' writings the 'second wave' appears mostly white and middle class, though this may partly be because the struggles of women of colour feminists tend to be written out of standard feminist accounts (Jonson 2016). As I have already said, we were there right at the 
beginning of WLM. Third wave also found the 'second wave' narrowly focussed on economic, educational, access and, by contrast regarded themselves as more inclusive and transformative in their goals. But, of course, one could take issue with the claim that economic, educational, and political access are narrow concerns. The point of inclusion was also addressed by women of colour in the 1970s but the more recent emphasis on intersectionality is new. Scholarship on sexuality has developed and expanded in a hugely significant way, to the extent that now there are book titles such as 'After Queer Theory'. The question of fluid sexual identities is not entirely new, but it has gained a very significant momentum now. There has also been much wider emphasis recently on the trafficking of women globally, as it is on the struggles of refugee and migrant women reaching the southern shores of Europe from perilous journeys by land and by sea, many drowning on the way.

How useful the wave metaphor is remains an open question. However, different texts offer different chronologies, and such views and histories of waves have been challenged so that there is a destabilisation of standard chronologies. What is important is that we recognise the importance of building coalitions despite our differences and contestations. We need to address economic, political and cultural factors which impinge on our daily lives. And we develop a politics of inclusion at the local and the global level. 